\title{
不規則に変動する軸力とねじりの組合せ応力における疲労強度評価
}

\author{
松原 剛* 林田 篤**
}

\section{Fatigue Strength Estimation under Irregular Variable Combined Axial and Share Stresses}

by

\author{
Go Matsubara* and Atsushi Hayashida**
}

\begin{abstract}
The Wang-Brown or Dong methods were incorporated into the multiaxial high cycle constant-amplitude fatigue life prediction method proposed by the authors in the previous papers, so as to predict multiaxial high cycle irregular variable amplitude fatigue life. Multiaxial high cycle fatigue tests were performed using SNCM439 steel for verification. The stress amplitude, mean stress, and principal stress direction change in the stress waveform of the tests. The fatigue lives predicted by the Wang-Brown method were about three times longer than the experimental values. By contrast, the Dong method predicted fatigue lives that were about one-third shorter than experiments. This is thought to be because the stress range of each path is calculated to be smaller by the Wang-Brown method and larger by the Dong method in the stress waveform converted into Euclidean coordinates.
\end{abstract}

\section{Key words}

Fatigue life, High cycle, Multiaxial fatigue, Life prediction, Variable stress, Principal stress direction

\section{1 緒言}

輸送機械を構成する機械部品は多軸応力で高サイクル 領域まで運用されることが多く, 疲労限度設計が多くな るが, 軽量化や他部品との取合いから疲労限度を多少超 える応力が発生することもあり, 高サイクル寿命設計も 行われる. 両設計に用いられる評価パラメータは, 作業効 率の観点から同一であることが好ましい。そこで筆者ら は，多軸一定振幅疲労で塑性変形が小さいか無視できる 程度の高サイクル領域を対象に, 各種の波形, 位相差, 平 均応力の疲労強度への影響を考慮できる応力をパラメー タとする疲労限度および高サイクル寿命の評価法を提案 してきた ${ }^{1) ~ 4)}$. 一方, 実機での実働荷重を考えると多軸変 動振幅荷重下での疲労寿命評価も重要であり, 一定振幅 疲労評価のパラメータが適用可能となれば，より設計効 率の向上が計れることとなる. なお, 塑性変形を考慮す心゙ き疲労評価の場合は，ひずみ経路に対する材料依存性も 評価する必要があり, 伊藤らの提案する評価法は有効な 方法と考えられる ${ }^{5}$.

ところで, Fatemi らは多軸変動振幅荷重下での疲労寿 命を評価するための 3 つの必須要素として, サイクルカ ウント法, 多軸疲労評価パラメータ, 累積損傷則を指摘し ている ${ }^{6}$. 彼らは, この内の累積損傷則について, 多くの 非線形累積損傷則が提案されているが，線形則に起因す る欠点のいくつかは, 評価パラメータに起因することを 指摘している. そこで筆者らは, 多軸変動振幅疲労の評価 法としてサイクルカウント法, 寸なわち変動応力振幅の
算定法を中心に, 近年の多軸疲労破壊国際会議等 ${ }^{77,8)}$ にお ける文献調査を行った. その結果, 提案されている評価法 は, クリティカルプレーン法 9), 10)や有効応力法 11), 12)など の従来の多軸一定振幅疲労評価法を元にしており, 応力 振幅の算定法に違いのあることがわかった.

多軸変動振幅疲労評価法で, クリティカルプレーン法 を用いるのは Bannantine-Socie の方法 ${ }^{13)}$, 有効応力法を用 いるのは Wang-Brown の方法 ${ }^{14)}$, Dong らの方法 ${ }^{15) な と ゙ て ゙ ~}$ ある. Bannantine-Socie の方法 ${ }^{13}$ は, クリティカル面の垂 直応力とせん断応力のそれぞれについて，レインフロー 法による応力頻度算定を行う。累積損傷評価に用いる S$\mathrm{N}$ 曲線は, 垂直応力に SWT 基準 10)を, せん断応力に Fatemi-Socie 基準 9)を用いる. 最終的な予測破断寿命は, それぞれ推定される寿命の内の短い寿命が採用される. この評価は, それぞれの S-N 曲線に相関性がなく, 両応 力を個別に評価することから, 疲労強度への応力の組合 せの影響が十分には考慮されていないなどの指摘がある 14). また, 有効応力法を元にする Wang らの方法は ${ }^{14)}$, 多 軸応力をミーゼスの相当ひずみに換算して, その相対值 を用いることでレインフロー法の適用を可能にした。し かし, ひずみ值の差分を評価するだけで, ひずみ值間の応 力経路の違いは評価しない. そこで, Dong らは, 応力経 路を $\sigma-\sqrt{ } \beta \tau$ 座標上に表示して, その応力経路の距離を評 価する方法を提案した ${ }^{15)}$.

一方, これらの検証に用いられるデータは, 筆者らが調 ベた範囲では低サイクル寿命領域のデータが多く 13) 15),

$\dagger$ 原稿受理 令和2年4月3日 Received Apr. 3, $2020 @ 2021$ The Society of Materials Science, Japan

* 正会 員 川崎重工業(株) 技術研究所 $\bar{T} 673-8666$ 明石市川崎町

Technical Institute, Kawasaki Heavy Industries, Ltd., Kawasaki-cho, Akashi, 673-8666.

** 賛助会員 川崎重工業(株) 航空宇宙カンパニー †504-8710 各務原市川崎町

Aerospace Company, Kawasaki Heavy Industries, Ltd., Kawasaki-cho, Kakamigahara, 504-8710. 
高サイクル寿命領域のデータは Li らが実施した平均応力 一定で応力振幅を規則的に変化させる多軸多段多重疲労 試験データなどであった ${ }^{16)}$. 1 ブロック中に応力振幅, 平 均応力，主軸の方向が変化する多軸疲労試験データは, Wang らが実施した低サイクル寿命領域のデータのみで あった ${ }^{17)}$.さらに, Wang-Brown 法と Dong らの方法に対 して，同一の評価パラメータで詳細な比較を行った事例 もなかった。

そこで本論文では，高サイクル領域における不規則に 変動する軸力とねじりの組合せ応力下の疲労強度評価法 の検討として，筆者らが提案している応力基準のパラメ 一タに, 累積損傷則は修正マイナ一則を, サイクルカウン 卜に有効応力法の代表的なカウント法である Wang-Brown 法と Dong らの方法を用いて, 変動振幅荷重評価の可能性 を調べることにする．検証試験は，SNCM439 に対して 1 ブロック中に応力振幅, 平均応力, 主軸の方向を変化させ る疲労試験で，両カウント法の違いが顕著になるような 負荷波形を設定する. 最後に, 破断試験片のマクロ観察を 行い，破壊機構についての考察を行う。

\section{2 多軸変動振幅下の高サイクル疲労寿命評価方法}

\section{$2 \cdot 1$ 評価パラメータ}

評価パラメータは, 応力振幅に等価せん断応力振幅 $\sqrt{ } \mathrm{J}_{2, \mathrm{amp}}$ を, 平均応力に相当する評価パラメータに $\mathrm{S}_{\max }$ を, 等価応力振幅に統一的等価せん断応力振幅 $\sqrt{ } \mathrm{J}_{2, \mathrm{amp}, \mathrm{eq}}$ を用 いる. $\mathrm{S}_{\max }$ と $\sqrt{\mathrm{J}_{2, \mathrm{amp}, \mathrm{eq}}}$ は, 筆者らが既報にて提案したパラ メータである ${ }^{14), 15)}$.

\section{【 $\sqrt{\mathrm{J}_{2}}$ の定義】}

時刻 $\mathrm{t}$ における忘力成分 $\sigma_{\mathrm{x}}, \sigma_{\mathrm{y}}, \sigma_{\mathrm{z}}, \tau_{\mathrm{xy}} ， \tau_{\mathrm{yz}} ， \tau_{\mathrm{zx}}$ を評価 対象とする. 時刻 $\mathrm{t}$ における応力成分を, 偏差応力テンソ ル $\mathrm{S}_{\mathrm{ij}}$ に変換，さらに式(1)を用いて応力 $\mathrm{S}_{\mathrm{i}}$ へ変換する．等 価せん断応力 $\sqrt{J_{2}}$ は，式(2)と定義する.

筆者らは，塑性変形が小さいか無視できる程度の多軸 高サイクル領域の一定応力振幅疲労評価において，位相 差や負荷波形による応力経路の違いを表現する応力振幅 として, $\mathrm{S}_{\mathrm{i}}$ 軸のユークリッド空間座標上の応力軌跡の経路 距離を用いてきた. 距離の算定には, 簡便さと距離の算出 精度から式(3)の Mamiya の方法を用いた ${ }^{3), 4)}$. Mamiya の 方法は, $\mathrm{S}$ i 軸のユークリッド空間座標上の応力軌跡を包括 する最小四角柱の対角線長さを求めるもので，対角線長 さの半分を応力振幅とする.

この方法では，経路が交差する場合や次節で示す試験 波形 $\mathrm{A}$ のように応力軌跡が凹の場合には精度が期待出来 ない. そこで変動応力振幅でも， $\mathrm{S}_{\mathrm{i}}$ 軸のユークリッド空間 座標上の応力軌跡の経路距離を振幅とするが，その算定 に Wang-Brown 法と Dong らの方法を用いる.

$$
\begin{gathered}
\mathrm{S}_{1}=\frac{\sqrt{3}}{2} \mathrm{~s}_{\mathrm{xx}}, \quad \mathrm{S}_{2}=\frac{1}{2}\left(\mathrm{~s}_{\mathrm{yy}}-\mathrm{s}_{\mathrm{zz}}\right), \quad \mathrm{S}_{3}=\mathrm{s}_{\mathrm{xy}}, \\
\mathrm{S}_{4}=\mathrm{s}_{\mathrm{yz}}, \quad \mathrm{S}_{5}=\mathrm{s}_{\mathrm{zx}} \\
\sqrt{\mathrm{J}_{2}}=\sqrt{\mathrm{S}_{1}{ }^{2}+\mathrm{S}_{2}{ }^{2}+\mathrm{S}_{3}{ }^{2}+\mathrm{S}_{4}{ }^{2}+\mathrm{S}_{5}{ }^{2}}
\end{gathered}
$$

$$
\sqrt{\mathrm{J}_{2, \text { amp }}}=\sqrt{\sum_{\mathrm{i}=1}^{5}\left(\frac{\mathrm{S}_{\mathrm{imax}}-\mathrm{S}_{\mathrm{imin}}}{2}\right)^{2}}
$$

\section{【 $\mathrm{S}_{\max }$ の定義】}

筆者らは，平均応力に相当する評価パラメータとして $\mathrm{S}_{\max }$ を提案している. 評価する 1 サイクルにおいて, 評定 部に生じる垂直方向の変動応力の中で, 応力範囲が最大 となる方向の変動応力の内の最大值を $\mathrm{S}_{\max }$ と定義する.

純軸力疲労で応力振幅 $\sigma_{\mathrm{a}}$ が負荷される場合の $\mathrm{S}_{\max }$ は, 応力比 $\mathrm{R}=-1$ で $\mathrm{S}_{\max }=\sigma_{\mathrm{a}}, \mathrm{R}=0$ で $\mathrm{S}_{\max }=2 \sigma_{\mathrm{a}}$ となる. 純ねじり 疲労で応力振幅 $\tau_{\mathrm{a}}$ の $\mathrm{R}=-1$ のときは, $\mathrm{S}_{\max }=\tau_{\mathrm{a}}$ となる。ま た, 変動軸応力 $\sigma_{\mathrm{x}}$ と負荷方向が $90^{\circ}$ 異なる方向の一定軸 応力 $\sigma_{\mathrm{y}}$ の二軸応力の場合, $\sigma_{\mathrm{x}}$ の最大值を $\sigma_{\mathrm{x} \text { max }}$ とすると $\sigma_{\mathrm{y}}$ と $\sigma_{\mathrm{xmax}}$ との大小関係に関係な $\mathrm{S}_{\max }=\sigma_{\mathrm{xmax}}$ となる. $\mathrm{S}_{\max }$ の 定義は, 多軸疲労き裂進展挙動が, 変動応力範囲が最大と なる成分に対しての応力拡大係数に従うとともに，その 90方向へ進展することを根拠としている ${ }^{18), 19) .}$

\section{【 $\sqrt{ } \mathrm{J}_{2, \mathrm{amp}, \mathrm{eq}}$ の定義】}

Fig. 1 は筆者らの提案する耐久限度線図である.実線は, 筆者らが既報で提案した多軸疲労限推定法による疲労限 を表わす 1), 2). 推定法における材料定数の真破断応力 $\sigma_{\mathrm{T}}$ と純軸力における $\mathrm{R}=-1$ の疲労限 $\sigma_{\mathrm{w}}$ と, 実線から推定さ れる純軸力の $\mathrm{R}=0$ の疲労限 $\sigma_{\mathrm{u}}$ と純ねじりの $\mathrm{R}=-1$ の疲労 限 $\tau_{\mathrm{w}}$ を図示する. 純軸力で平均応力のある場合の疲労限 は, 実線より修正グッドマン則と同じ值が推定される. 単 軸の試験結果についても, 従来の推定法よりも高い精度 で推定出来ることを確認している11).

図中の一点鎖線は, 同一の有限寿命となる応力条件を 表わす. 破線は $\mathrm{R}=-1$ の軸力の応力条件を表す. 平均応力 が考慮された等価応力 $\sqrt{J_{2, a m p, e q}}$ は, 一点鎖線と破線との交 点として定義する. 式(4)は一点鎖線を, 式(5)は破線を表 わす。統一的等価せん断応力振幅 $\sqrt{ } \mathrm{J}_{2, \mathrm{amp}, \mathrm{eq}}$ は，式(4)と

$$
\begin{gathered}
\sqrt{\mathrm{J}_{2, \mathrm{amp}}}+\alpha_{\mathrm{A}} \mathrm{S}_{\max }=\beta_{\mathrm{A}} \\
\text { ただし, } \alpha_{\mathrm{A}}=\frac{\sqrt{\mathrm{J}_{2, \mathrm{amp}, \mathrm{A}}}}{\sigma_{\mathrm{T}}-\mathrm{S}_{\max , \mathrm{A}}}, \beta_{\mathrm{A}}=\frac{\sigma_{\mathrm{T}} \sqrt{\mathrm{J}_{2, \mathrm{amp}, \mathrm{A}}}}{\sigma_{\mathrm{T}}-\mathrm{S}_{\mathrm{max}, \mathrm{A}}} \\
\frac{\sqrt{\mathrm{J}_{2, \mathrm{amp}}}}{\mathrm{S}_{\max }}=\frac{1}{\sqrt{3}} \\
\sqrt{\mathrm{J}_{2, \text { amp } \mathrm{eq}}}=\frac{\sigma_{\mathrm{T}} \sqrt{\mathrm{J}_{2, \mathrm{amp}, \mathrm{A}}}}{\sigma_{\mathrm{T}}-\mathrm{S}_{\max , \mathrm{A}}+\sqrt{3} \sqrt{\mathrm{J}_{2, \mathrm{amp}, \mathrm{A}}}}
\end{gathered}
$$

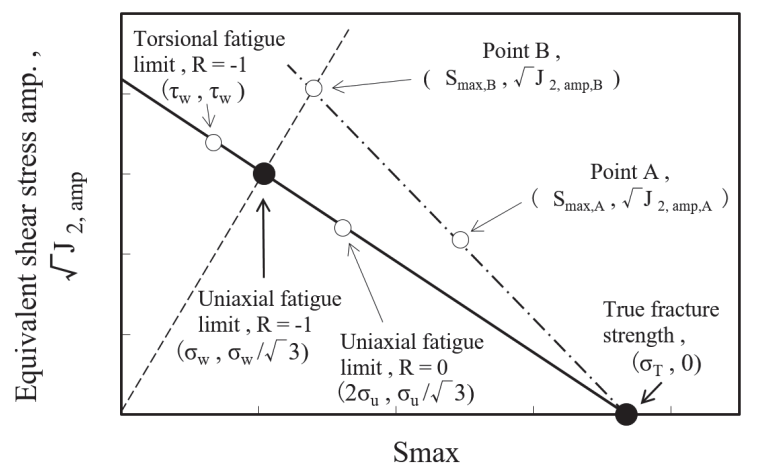

Fig.1 Relationship between $\sqrt{ } J_{2, \text { amp }}$ and $S_{\max }$. 
式(5)から式(6)と表される．点 A の応力状態に対して, 点 $\mathrm{B}$ が同一の有限寿命となる等価応力状態を表す.

\section{$2 \cdot 2$ サイクルカウント法と累積損傷則}

本節では, 疲労試験で用いる負荷波形を用いて, サイク ルカウント法と累積損傷則を説明する.

$2 \cdot 2 \cdot 1$ 負荷波形 疲労試験に用いる負荷波形 $\mathrm{A} 1$ を説 明する.負荷波形 A1 の各時刻における応力を Table 1 に, 時間履歴を Fig. 2 に示す. Fig. 2 には軸力応力 $\sigma$ とねじ り応力 $\tau$ と等価せん断応力 $\sqrt{\mathrm{J}_{2}}$ を示す. $\mathrm{A} 1$ には 1 ブロッ

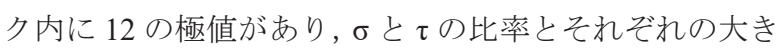
さが変化する. 組合せ応力比 $\tau / \sigma$ は， 0 から 2 の範囲で 変化する， $\tau / \sigma$ が変化することで主軸方向も変化する.

Time1 で $\tau, \sqrt{ } \mathrm{J}_{2}, \tau / \sigma$ は最大值となる. Time10 では, Time1 ののとてのそれぞれで応力比 $\mathrm{R}=-1$ の関係となっている.

Fig. 3 に応力 $\mathrm{S}_{\mathrm{i}}$ のユークリッド空間座標における負荷波 形 A1 の応力軌跡を示す. なお疲労試験は, 負荷波形 A1 の各応力の極值を比例倍させた波形 $\mathrm{A} 1$ ～A5 で実施した. $2 \cdot 2 \cdot 2$ Wang-Brown 法 多軸変動振幅疲労の場合, 時 間軸に対して複数の応力が不規則に変化するので，それ ぞれの応力にレインフロー法を適用するとサイクル位置 が異なるなどの問題が生じる.また, 多軸応力をミーゼス 相当ひずみに変換するとミーゼスひずみは常に正となる ことから, 引張と圧縮の違いを表現出来ずに応力範囲を 過小評価することになる. そこで Wang らは，ミーゼス相 当ひずみの相対值を用いることで，レインフロー法の適 用を可能とした ${ }^{8)}$.ただし，相対的な相当ひずみは，相当 ひずみの極值の差分を評価するので，位相差の有無によ る極值間の応力経路の違いは表現出来ない.

本研究では，ミーゼス相当ひずみの代わりに等価せん 断応力を用いる. 以下に Wang-Brown 法の説明を行う.

Wang-Brown 法は, 評価対象となる時歴データの中で $\sqrt{ } \mathrm{J}_{2}$ が最大となる時刻のデータを，最初の経路の開始点とす る. 残りの時歴データについては, 相対的な等価せん断応 力 $\Delta \sqrt{ } \mathrm{J}_{2}$ として, 経路の開始点の $\sqrt{ } \mathrm{J}_{2}$ との差で表す. 経路 の終点は, $\Delta \sqrt{ } \mathrm{J}_{2}$ が最も大きな值となる時刻のデータとす る. 開始点から終点までの経路は, 片道なので 0.5 サイク ルとする. 2 番目の経路については, 最初の経路の終点を 開始点として， $\Delta \sqrt{ } \mathrm{J}_{2}$ は 2 番目の経路の開始点の $\sqrt{ } \mathrm{J}_{2}$ との 差で表す. 2 番目の経路の終点も， $\Delta \sqrt{ } \mathrm{J}_{2}$ が最大となる点

Table 1 Stress values in stress path A1.

\begin{tabular}{|c|c|c|c|c|c|c|c|}
\hline & $\sigma$ & $\tau$ & \multirow{2}{*}{$\tau / \sigma$} & $\mathrm{S} 1$ & $\mathrm{~S}_{3}$ & $\mathrm{~J}_{2}$ & $\mathrm{Smax}$ \\
\cline { 2 - 4 } & $\mathrm{MPa}$ & $\mathrm{MPa}$ & & $\mathrm{MPa}$ & $\mathrm{MPa}$ & $\mathrm{MPa}$ & $\mathrm{MPa}$ \\
\hline Time 1 & 275 & 550 & 2.00 & 159 & 550 & 572 & 704 \\
\hline Time 2 & -440 & -165 & 0.38 & -254 & -165 & 303 & 55 \\
\hline Time 3 & -110 & -165 & 1.50 & -64 & -165 & 177 & 119 \\
\hline Time 4 & 55 & 0 & 0.00 & 32 & 0 & 32 & 55 \\
\hline Time 5 & -275 & -110 & 0.40 & -159 & -110 & 193 & 39 \\
\hline Time 6 & 275 & 440 & 1.60 & 159 & 440 & 468 & 598 \\
\hline Time 7 & 440 & 275 & 0.63 & 254 & 275 & 374 & 572 \\
\hline Time 8 & -110 & -275 & 2.50 & -64 & -275 & 282 & 225 \\
\hline Time 9 & -550 & -275 & 0.50 & -318 & -275 & 420 & 114 \\
\hline Time 10 & -275 & -550 & 2.00 & -159 & -550 & 572 & 429 \\
\hline Time 11 & 550 & 275 & 0.50 & 318 & 275 & 420 & 664 \\
\hline Time 12 & 275 & 550 & 2.00 & 159 & 550 & 572 & 704 \\
\hline
\end{tabular}

とする. 3 番目の経路の開始点は, 2 番目の経路の終点と する. Wang-Brown 法は, この繰返しである. 各経路にお ける応力振幅は, 終点の $\Delta \sqrt{ } \mathrm{J}_{2}$ の半分とする.

以下に負荷波形 A1 を用いて, 具体的な説明を行う. Fig. 4 に負荷波形 A1 の時刻における相対的な等価せん断応力 $\Delta \sqrt{ } \mathrm{J}_{2}$ を示す。(a)図の経路 1 の開始点は, 負荷波形 $\mathrm{A} 1$ に おいて $\sqrt{ } \mathrm{J}_{2}$ が最大となる時刻 1 とする. 経路 1 は, 時刻 2 において時刻 2'へ移動して時刻 2'より時刻 8, 時刻 9 一 続き, $\Delta \sqrt{ } \mathrm{J}_{2}$ すなわち時刻 1 からの相対的な $\sqrt{ } \mathrm{J}_{2}$ が最大と なる時刻 10 で終点となる. 次に, 時刻 10 を開始点とす る経路 10 では, 開始点が時刻 10 で終点が $\Delta \sqrt{ } \mathrm{J}_{2}$ が最大と なる時刻 12 となる。両経路の応力範囲は, 終点の $\Delta \sqrt{ } \mathrm{J}_{2}$ の值で, 図中の上下方向の矢印の長さの值となる. (b)図 では，時刻 2 から時刻 2’までの経路を示す。経路 2 は, 時刻 2 を開始点として時刻 4 において時刻 4 ’ 移動して 時刻 6 で終点とする. 経路 6 は時刻 6 を開始点として, 時刻 2'を終点とする. 両経路の応力範囲は, (a)図と同様 に終点の $\Delta \sqrt{ } \mathrm{J}_{2}$ の值で, 図中の上下方向の矢印の長さの值 となる. (c)図は, 時刻 4 から時刻 4 ’までの経路を示す. 時刻 4 を開始点とする経路 4 , 時刻 5 を開始点とする経路

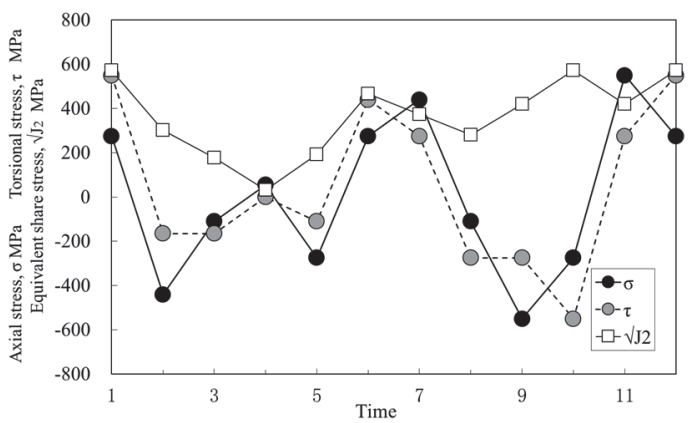

Fig.2 Stress path A1 as time history data format.

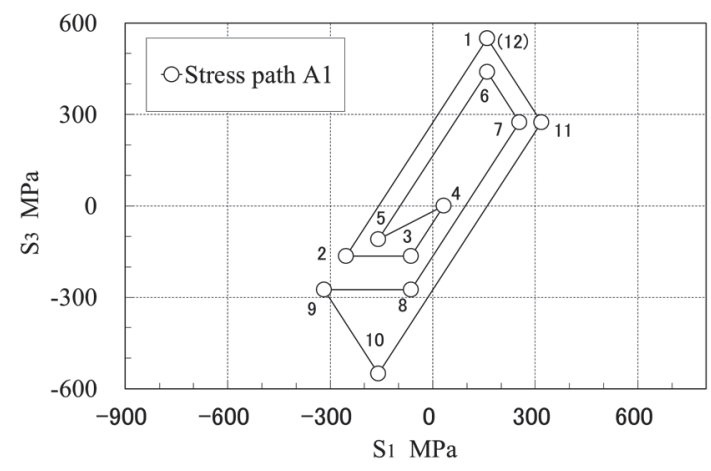

Fig.3 Stress path $\mathrm{A} 1$ in $\mathrm{S}_{3}-\mathrm{S}_{1}$.

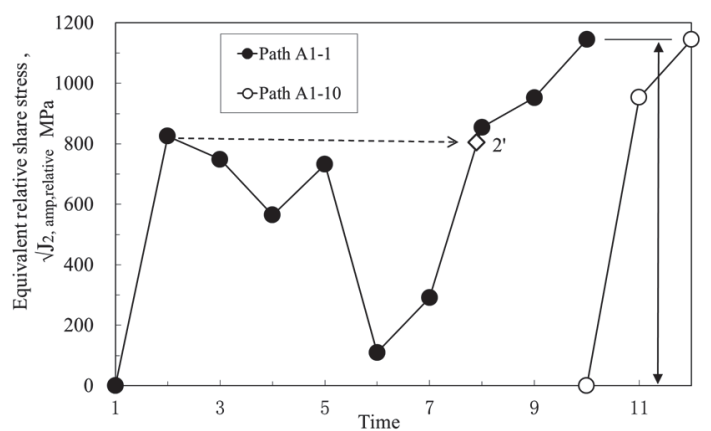

(a) Equivalent relative share stress for Path 1 and Path 10. 


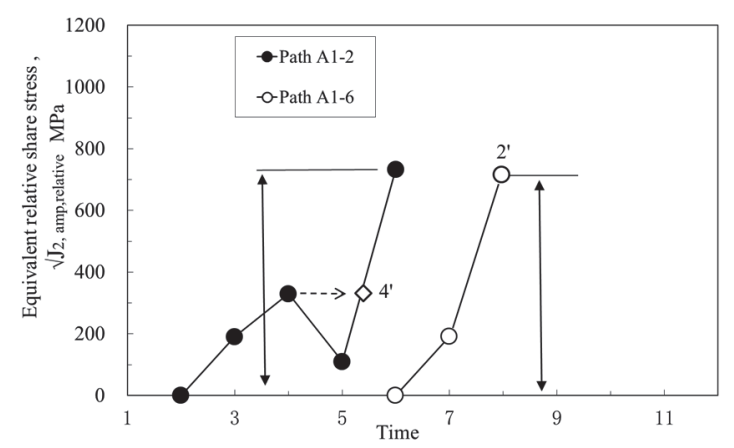

(b) Equivalent relative share stress for Path 2 and Path 6.

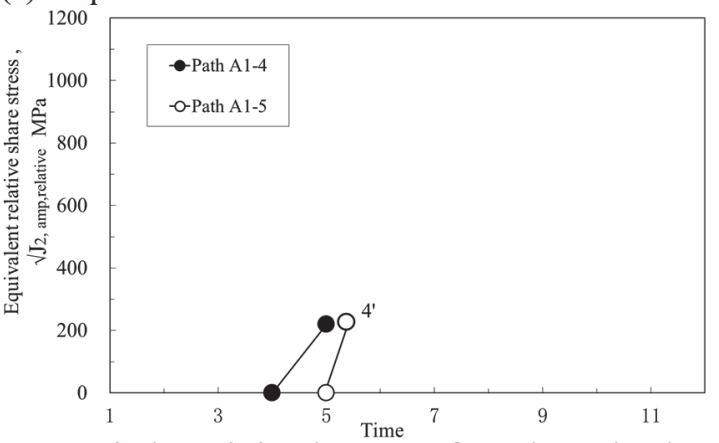

(c) Equivalent relative share stress for Path 4 and Path 5.

Fig.4 Equivalent relative share stress for stress path A1.

5 を表す.両経路の応力範囲は, 終点の $\Delta \sqrt{ } \mathrm{J}_{2}$ の值となる. 応力振幅は, 応力範囲の半分の值である.

次に, 各経路の統一的等価せん断応力振幅 $\sqrt{ } \mathrm{J}_{2, \mathrm{amp}, \mathrm{eq}}$ を求 める. 最初に, 各経路における $\mathrm{S}_{\max }$ を算出する. 各経路の $\mathrm{S}_{\max }$ と先に求めた応力振幅 $\sqrt{ } \mathrm{J}_{2, \mathrm{amp}}$ から, 式(6)を用いて統 一的等価せん断応力 $\sqrt{ } \mathrm{J}_{2, \mathrm{amp}, \mathrm{eq}}$ を求める.

$2 \cdot 2 \cdot 3$ Dong らの方法 Wang-Brown 法が相当ひずみ間 の応力経路の違いを表現出来ないことに対して, Dong ら は応力経路を $\sigma-\sqrt{ } \beta \tau$ 座標に表示，その応力経路の距離を 評価する方法を提案した ${ }^{9}$. $\beta$ は疲労強度等価係数で, 時 間強度における軸力強度とせん断強度の平均的な比率を 表す．鋼の場合は，通常 2〜4になる. 最初の経路の開始 点は, Wang-Brown の方法と同様に $\sqrt{ } \mathrm{J}_{2}$ が最大となる点と する. 経路の終点は, $\sigma-\sqrt{ } \beta \tau$ 座標上で開始点から最も離れ た点とする．２番目の経路の開始点は，1番目の経路の終 点で，2 番目の経路の終点は，2 番目の経路の開始点から 最も離れた点とする. 3 番目の経路の開始点は，2 番目の 経路の終点とする. Dong らの方法は, この繰返しである. 開始点から終点までの経路は 0.5 サイクルとする. 応力振 幅は, 開始点と終点との経路の距離の総和の半分の值で ある、詳細は 4 章に示す。

$2 \cdot 2 \cdot 4$ 累積損傷則 変動振幅荷重下の破断寿命 $\mathrm{N}_{\mathrm{f}}$ は, 修正マイナー則を用いて求める。累積評価の基準となる S-N 曲線は，多軸一定振幅疲労における等価 S-N 曲線の 式(7)とする. 詳細は前報 ${ }^{14), 15)}$ と示した. 以下に，具体的 な $\mathrm{N}_{\mathrm{f}}$ の求め方を示す.

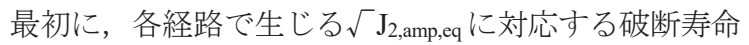
$\mathrm{N}_{\mathrm{i}}$ を等価 S-N 曲線から算出する. 次に, 各経路が 1 回負 荷されるときの損傷度 $\mathrm{d}_{\mathrm{i}}=0.5 / \mathrm{N}_{\mathrm{i}}$ を求める. 分子の 0.5 は,
前述の経路計算で各経路を 0.5 サイクル分で算定してい るためである。最後に, $\mathrm{N}_{\mathrm{f}}$ は $\Sigma \mathrm{D}_{\mathrm{i}}\left(=\mathrm{N}_{\mathrm{f}} \times \Sigma \mathrm{d}_{\mathrm{i}}\right)$ が 1 になると きの回数として, 式(8)で表される.

$$
\begin{aligned}
& \quad \sqrt{\mathrm{J}_{2, \mathrm{amp}, \mathrm{eq}}} \mathrm{mc} \times \mathrm{N}_{\mathrm{f}}=\mathrm{Cc} \\
& \text { ただし } \\
& \mathrm{mc}=\log \frac{\mathrm{N}_{3}}{\mathrm{~N}_{\mathrm{w}}} \div \log \frac{\sqrt{\mathrm{J}_{2, \mathrm{amp}, \mathrm{eqw}}}}{\sqrt{\mathrm{J}_{2, \mathrm{amp}, \mathrm{eq} 3}}}, \mathrm{Cc}={\sqrt{\mathrm{J}_{2, \mathrm{amp}, \mathrm{eqw}}}}^{\mathrm{mc}} \times \mathrm{N}_{\mathrm{w}} \\
& \mathrm{N}_{3}: 1 \times 10^{3} \text { 回 } \\
& \mathrm{N}_{\mathrm{w}}: \text { 一定応力振幅における疲労限の折れ曲り点 } \\
& \text { とする回数 }
\end{aligned}
$$

$$
\mathrm{N}_{\mathrm{f}}=\frac{1}{\sum_{\mathrm{i}=1}^{\mathrm{r}} \mathrm{d}_{\mathrm{i}}}
$$

\section{3 多軸疲労試験による基準の検証}

\section{$3 \cdot 1$ 疲労試験方法}

試験に用いる材料は SNCM439 である. Table 2 に化学 成分を, Table 3 に熱処理条件を示寸. 引張強さは $1106 \mathrm{MPa}$, 降伏応力は $1027 \mathrm{MPa}$, 真破断応力は $1693 \mathrm{MPa}$ である. 試 験片形状を Fig. 5 に示す. 疲労試験には, 電気・油圧サー ボ式軸力ーねじり複合疲労試験機（荷重容量 $\pm 100 \mathrm{kN}$, トル ク容量 $\pm 1 \mathrm{kNm}$ ) を用いる. 疲労試験は, 荷重制御とトルク 制御で行う. 変動振幅疲労試験は, Table 1 の波形 A1 を基 準として，A1 の極值を比例倍させた 5 段階の応力レベル で実施する. A1 以外の応力条件を Table 4 に示す. なお, 一定振幅疲労試験として, 応力比 $\mathrm{R}=-1$ の条件下で, 純軸 力, 軸力とねじりの組合せ応力比 $\tau_{\mathrm{a}} / \sigma_{\mathrm{a}}$ が 0.29 と 0.80 の 3 種類の試験も実施する.

Table 2 Chemical composition.

\begin{tabular}{|c|c|c|c|c|c|c|c|c|}
\hline $\mathrm{C}$ & $\mathrm{Mn}$ & $\mathrm{Si}$ & $\mathrm{P}$ & $\mathrm{S}$ & $\mathrm{Cr}$ & $\mathrm{Ni}$ & $\mathrm{Mo}$ & $\mathrm{Co}$ \\
\hline $0.38 \sim$ & $0.65 \sim$ & $0.15 \sim$ & $\leqq$ & $\leqq$ & $0.70 \sim$ & $1.65 \sim$ & $0.20 \sim$ & $\leqq 0.35$ \\
0.43 & 0.85 & 0.35 & 0.025 & 0.025 & 0.90 & 2.00 & 0.30 & \\
\hline
\end{tabular}

Table 3 Heat treatment conditions.

\begin{tabular}{|c|c|c|}
\hline Normalization & Oil quenching & Tempered \\
\hline $885-9133^{\circ} \mathrm{C}$ & $802-8433^{\circ} \mathrm{C}$ & $450-500{ }^{\circ} \mathrm{C}$ \\
$75 \mathrm{~min}$ & $75 \mathrm{~min}$ & $130 \mathrm{~min}$ \\
\hline
\end{tabular}

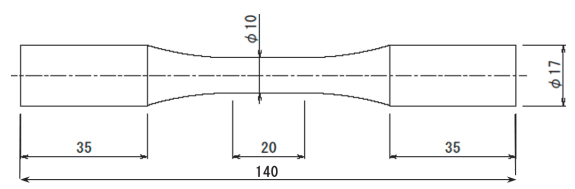

Fig. 5 Fatigue test specimen.

\section{$3 \cdot 2$ 疲労試験結果}

Fig. 6 に S-N 曲線を示す. 横軸は破断寿命を, 縦軸は各 試験片に負荷される軸応力の最大值を示寸. 波形 $\mathrm{A}$ の疲 労試験結果の縦軸は, 負荷波形の内で軸応力が最大の Time11の軸応力值で, 横軸は破断したブロック数である. 図中には後述する等価 S-N 曲線から推定した一定疲労試 験の $\mathrm{R}=-1$ の $\tau_{\mathrm{a}} / \sigma_{\mathrm{a}}=0.29,0.80,1.00$ の $\mathrm{S}-\mathrm{N}$ 曲線を示す. 軸 応力最大值の整理において疲労試験結果の強度は, 軸力, $\tau_{\mathrm{a}} / \sigma_{\mathrm{a}}=0.29,0.80$, 波形 $\mathrm{A}$ の順番で低下した。波形 $\mathrm{A}$ の縦 軸に用いた Time11 の $\tau / \sigma$ は 0.5 であるが，波形自体は 
Table 4 Stress values in stress path A2, A3 and A4.

\begin{tabular}{|c|c|c|c|c|c|c|c|c|}
\hline \multirow{4}{*}{$\begin{array}{c}\text { Ratio } \\
\text { per } \\
\text { A-1 }\end{array}$} & \multirow{2}{*}{\multicolumn{2}{|c|}{ Path A-2 }} & \multirow{2}{*}{\multicolumn{2}{|c|}{$\frac{\text { Path A-3 }}{0.73}$}} & \multirow{2}{*}{\multicolumn{2}{|c|}{$\frac{\text { Path A-4 }}{0.65}$}} & \multirow{2}{*}{\multicolumn{2}{|c|}{$\frac{\text { Path A-5 }}{0.60}$}} \\
\hline & & & & & & & & \\
\hline & $\sigma$ & $\tau$ & $\sigma$ & $\tau$ & $\sigma$ & $\tau$ & $\sigma$ & $\tau$ \\
\hline & $\mathrm{MPa}$ & $\mathrm{MPa}$ & $\mathrm{MPa}$ & MPa & $\mathrm{MPa}$ & $\mathrm{MPa}$ & $\mathrm{MPa}$ & $\mathrm{MPa}$ \\
\hline Time 1 & 225 & 450 & 200 & 400 & 180 & 360 & 165 & 330 \\
\hline Time 2 & -360 & -135 & -320 & -120 & -288 & -108 & -264 & -99 \\
\hline Time 3 & -90 & -135 & -80 & -120 & -72 & -108 & -66 & -99 \\
\hline Time 4 & 45 & 0 & 40 & 0 & 36 & 0 & 33 & 0 \\
\hline Time 5 & -225 & -90 & -200 & -80 & -180 & -72 & -165 & -66 \\
\hline Time 6 & 225 & 360 & 200 & 320 & 180 & 288 & 165 & 264 \\
\hline Time 7 & 360 & 225 & 320 & 200 & 288 & 180 & 264 & 165 \\
\hline Time 8 & -90 & -225 & -80 & -200 & -72 & -180 & -66 & -165 \\
\hline Time 9 & -450 & -225 & -400 & -200 & -360 & -180 & -330 & -165 \\
\hline Time 10 & -225 & -450 & -200 & -400 & -180 & -360 & -165 & -330 \\
\hline Time 11 & 450 & 225 & 400 & 200 & 360 & 180 & 330 & 165 \\
\hline Time 12 & 225 & 450 & 200 & 400 & 180 & 360 & 165 & 330 \\
\hline
\end{tabular}

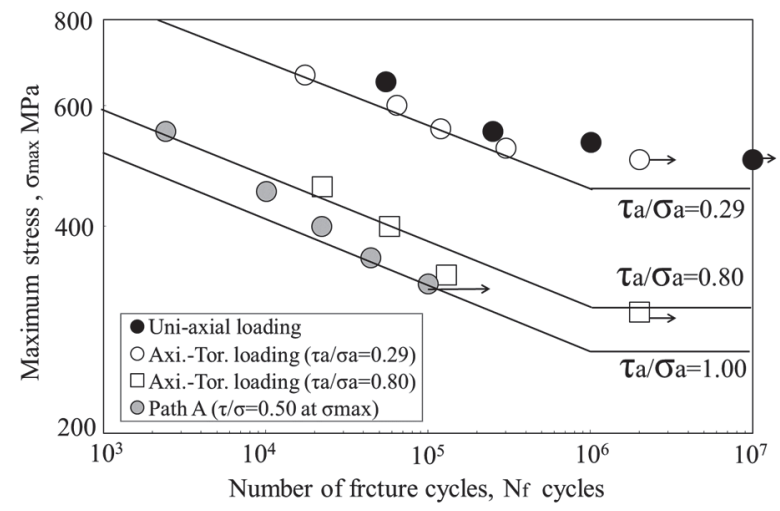

Fig. 6 S-N diagram at combined axial and torsion tresses.

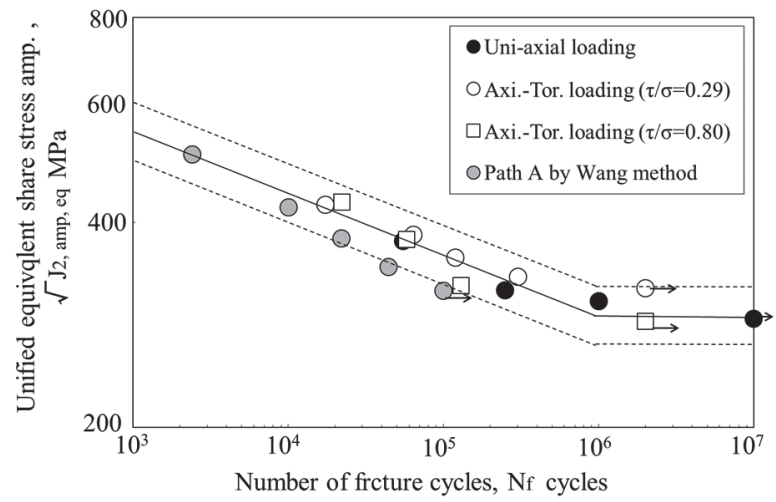

Fig. 7 S-N diagram at combined axial and torsion stresses.

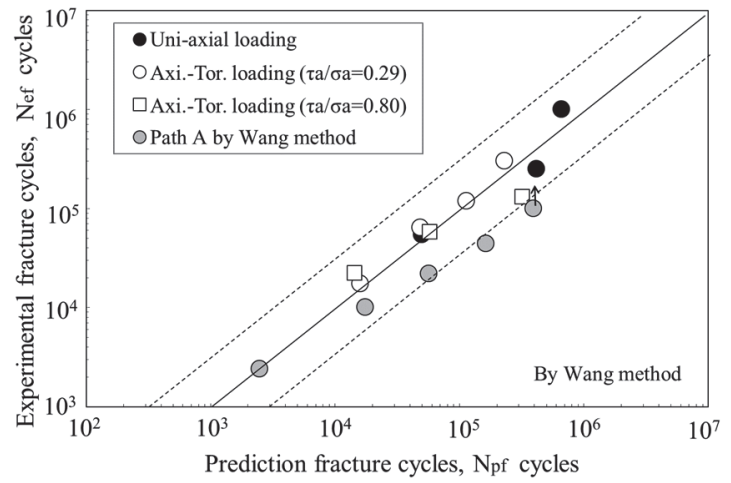

Fig. 8 Correlation between experimental life and predicted life for axial and torsional combined loading. $\tau / \sigma$ が 0 から 2 の範囲にあり, 試験結果は $\tau_{\mathrm{a}} / \sigma_{\mathrm{a}}=1.00$ の一 定疲労試験として推定される S-N 曲線付近に分布した。 波形 $\mathrm{A}$ の試験結果の縦軸と横軸の表示は, 一定振幅試験 結果の表示と異なるが，図中で線形関係が見られること， 負荷荷重に関係なく後述する破面様相がほぼ同じことか ら, 負荷波形に対応する破壊形態が得られていると推察 される. そのため 1 ブロックの損傷度を, 適切な評価パラ メータで適切な振幅にカウント出来れば，累積損傷則よ り寿命予測が可能になると考えられる.

Fig. 7 に等価 S-N 曲線を示す. 図中の実線は, 一定疲労 試験の破断寿命結果の最小二乗近似線である. S-N 曲線の 折れ曲り点は, 図中の実線と一定疲労試験の未破断結果 を考慮して $1 \times 10^{6}$ 回と設定した. 本研究では, この実線の 等価 S-N 曲線を累積評価の基準 S-N 曲線とする.破線は, 実線の $1 / 3$ 倍と 3 倍の寿命を表す. 波形 $\mathrm{A}$ による疲労試 験結果の $\sqrt{ } \mathrm{J}_{2, \text { amp,eq }}$ は, Wang-Brown 法により求めた. 軸力, $\tau_{\mathrm{a}} / \sigma_{\mathrm{a}}=0.29,0.80$ の疲労試験結果は, ばらつきも少なく, 実 線上に分布した. 一方, 波形 $\mathrm{A}$ による疲労試験結果の寿 命は，長寿命側になるほど基準 S-N 曲線よりも短めの寿 命となった。

Fig.8 に基準 S-N 曲線より推定された寿命を示す. 横軸 は予測寿命を, 縦軸は試験結果を示す. 破線は, 予測寿命 の $1 / 3$ 倍と 3 倍を表す. 一定振幅疲労試験の結果は, 実線 上に図示されており, 多軸一定振幅疲労の評価に $\sqrt{ } \mathrm{J}_{2, \mathrm{amp}, \mathrm{eq}}$ を用いることが妥当であることがわかる．波形 A の疲労 試験結果は，長寿命側になるほど害寿命よりも長めの寿 命を予測した. すなわち, 負荷した荷重が小さいほど, 発 生する $\sqrt{ } \mathrm{J}_{2, \mathrm{amp}, \mathrm{eq}}$ を小さく推定した。この理由として, Wang-Brown 法と提案した耐久限度線図の関係が考えら れる. Wang-Brown 法は, 後述するように各径路の $\sqrt{ } \mathrm{J}_{2, \mathrm{amp}}$ を実際の值よりも小さく推定する.一方, 提案した耐久限 度線図では換算式の式構成から，同一の $S_{\max }$ に対して $\sqrt{ } \mathrm{J}_{2, \mathrm{amp}}$ が想定される值よりも小さくなるほど, $\sqrt{ } \mathrm{J}_{2, \mathrm{amp}, \mathrm{eq}}$ も相対值に比較してより小さく算出される. さらに, 長寿 命側では負荷した荷重が小さく $\sqrt{ } \mathrm{J}_{2, \text { amp }}$ も小さくなるので, 長寿命側になるほど $\sqrt{ } \mathrm{J}_{2, \mathrm{amp}, \mathrm{eq}}$ を小さく推定して実寿命よ りも長めの寿命を予測したと考えられる.

\section{4 応力振幅算出法についての考察}

Dong らの方法は, 応力履歴における垂直応力範囲とせ 几断応力範囲の比率 $\beta$ を用意する必要があることや， $\sigma-$ $\sqrt{ } \beta \tau$ 座標を用いるので軸力とねじり応力の組合せ以外で の評価の取扱いが難しい. 一方, Wang-Brown 法は, 時歴 表示データから評価を行うので, 応力経路の違いを表現 し難い. そこで, 応力軌跡を応力 $\mathrm{S}_{\mathrm{i}}$ 軸のユークリッド空 間座標に表示することで, それらの課題を避けて, 両評価 法の検証を行う.

\section{$4 \cdot 1$ Wang-Brown法}

Wang-Brown 法の経路開始点は，ユークリッド座標にお いても負荷波形の中で $\sqrt{ } \mathrm{J}_{2}$ が最大となる点である. 終点は ユークリッド座標上で経路開始点から最も離れた点で, 
応力範囲は開始点と終点との直線距離となる.

以下に負荷波形 A1 を用いて, 具体的な説明を行う. Fig. 9 にユークリッド空間座標における負荷波形 A1 の応力軌 跡を示す. (a)図に経路 1 と経路 10 を，(b)図に経路 2 と経 路 6 を, (c)図に経路 4 と経路 5 を示す. (a)図の経路 1 は, 点 1 が最大の $\sqrt{ } \mathrm{J}_{2}$ となり, 点 1 を開始点として最も離れ た点 10 を終点とする. 経路 1 の応力範囲は, 点 1 と点 10 との直線距離で図中の破線矢印となる. 経路 1 は, 点 1 か ら点 2 への経路があり, 開始点の点 1 を中心として点 1 と 点 2 の距離を半径とした円と, 点 7 から点 8 への経路と の交点を点 2 'とした場合，経路は転回点 2 から投影され た転回点 2 ’ 一継続する。 その後は, 点 2 ’ から点 8 , 点 9 と 経由して終点 10 一到達寸る. 経路 10 は, 経路 1 の終点 10 が開始点となり, 点 11 を経由して最も離れた点 12 (点 1）が終点となる. 経路 10 の忘力範囲は点 10 と点 12 の 直線距離で, 図中の破線矢印となる。(b)図の経路 2 は, 開始点を点 2 , 終点 6 となる. 経路 2 は, 点 2 から点 3 , 転回点 4, 投影された転回点 4' と経由して終点 6 となる経 路である. 経路 2 の応力範囲は点 2 から終点 6 までの直 線距離で，(b)図中の破線矢印となる，経路 6 は，開始点 6 で終点 2'とする経路である. (c)図の経路 4 は, 開始点 4 で終点 5 となる. 経路 5 は, 開始点 5 で終点 4 ' となる.

この方法で算出した各経路の応力範囲は, Fig. 4 の時刻 歴表示を用いて算出した值と同一の值となる。この方法 による応力範囲は, 開始点と終点との直線距離で表され ており, 経路の距離としては最小の值を算定する. 例えば, 経路 10 において, 点 11 を経由する経路は考慮されない. そのため, Wang-Brown 法は各経路の $\mathrm{d}_{\mathrm{i}}$, 実際の $\mathrm{d}_{\mathrm{i}} よ り$ も小さめに予測したと考えられる.

\section{$4 \cdot 2$ Dongらの方法}

前節と同様に, Fig. 9 の負荷波形 A1 を用いて Dong ら の方法の説明を行う. Dong らの方法による経路 1 の応力 範囲は, 点 1 と点 2 , 点 2 と点 8 , 点 8 と点 9 , 点 9 と点 10 の各距離の総和に, さらに点 2 と点 2 'の距離を加える.

経路 10 の応力範囲は, 点 10 と点 11 , 点 11 と点 12 の距 離の総和となる. 経路 2 の応力範囲は, 点 2 と点 3 , 点 3 と点 4 , 点 4 ' と点 6 の距離の総和に, さらに点 4 と点 4 'の 距離を加える. 経路 6 の応力範囲は, 点 6 と点 7 , 点 7 と 点 2 の距離の総和となる. 経路 4 の応力範囲は, 点 4 と 点 5 の距離, 経路 5 の応力範囲は, 点 5 と点 4 'の距離と なる.

\section{$4 \cdot 3$ 両方法の比較}

Table 5 に Wang-Brown 法と Dong らの方法による波形 A1 の各経路における応力範囲と疲労破壊が生じるときの 損傷度 $\mathrm{D}_{\mathrm{i}}\left(=\mathrm{N}_{\mathrm{f}} \times \mathrm{d}_{\mathrm{i}}\right)$ を示す. 経路 1 は, 両評価法の違いが 顕著に表れる経路である. Wang-Brown 法は経路 1 と経路 10 の $\mathrm{D}_{\mathrm{i}}$ がともに 0.49 に対して, Dong らの方法は 0.87 と 0.12 となる. ただし, Dong らの方法による経路 10 の $\sqrt{ } \mathrm{J}_{2, \text { amp,eq }}$ は, Wang-Brown 法の算定值よりも大きい. これ は, Dong らの方法で算出した経路 1 の $\mathrm{D}_{\mathrm{i}}$ が非常に大きい ことを示す. Dong らの方法による経路 1 の $\sqrt{ } \mathrm{J}_{2, \mathrm{amp}, \mathrm{eq}}$ は,

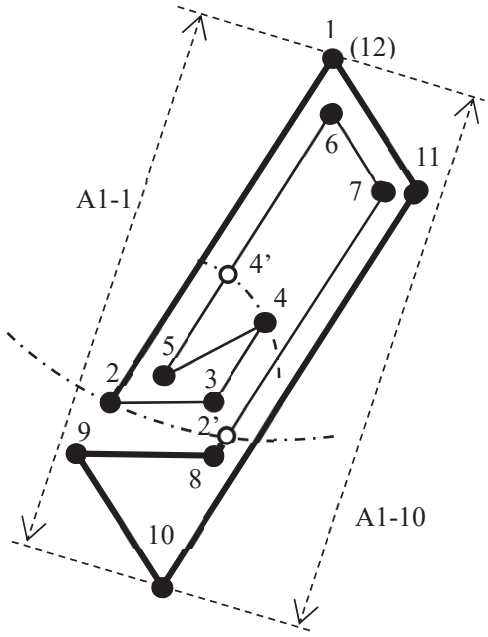

(a) Path A1-1 and Path A1-10

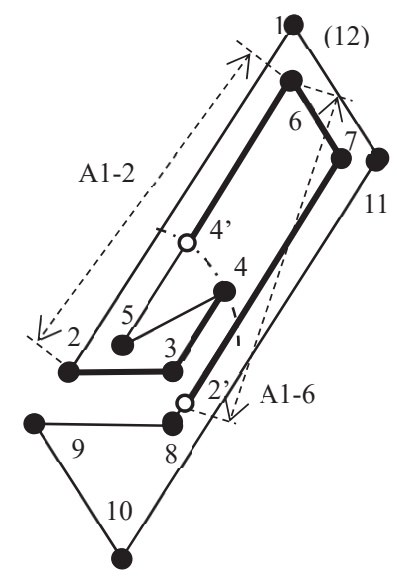

(b) Path A1-2 and Path A1-6

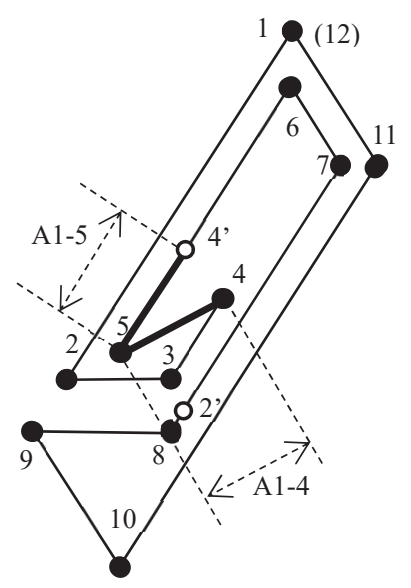

(c) Path A1-4 and Path A1-5

Fig. 9 Stress Path A-1.

経路 10 に対して $\mathrm{S}_{1}$ 方向で点 2 と点 2 'の経路と, 点 8 と 点 9 の経路が加わることで非常に大きい. また, 経路 1 と 経路 10 の損傷度 $\mathrm{D}_{\mathrm{i}}$ の合計は, Wang-Brown 法で 0.98, Dong らの方法で 0.99 とこの二つの経路が破壊の主因で あることを意味する。

Table 6 に負荷波形 A1 から A5 までの予測破断寿命と 実験での破断寿命を示す. A5 は未破断試験であり, 破断 寿命には試験の打切り回数を示した. Fig. 10 は, Fig. 8 に Dong らの方法による予測結果を追記したものである. 
Table 5 Stress values in each stress path.

\begin{tabular}{|c|c|c|c|c|c|c|c|c|c|}
\hline \multirow{2}{*}{\multicolumn{2}{|c|}{ Path }} & \multicolumn{4}{|c|}{ Wang-Brown method } & \multicolumn{4}{|c|}{ Dong Metohd } \\
\hline & & $\Delta \sqrt{ } \mathrm{J}_{2}$ & Smax & $\sqrt{J_{\text {req,amp }}}$ & $\mathrm{Di}$ & $\Delta \sqrt{ } \mathrm{J}_{2}$ & Smax & $\sqrt{J_{\text {req,anp }}}$ & Di \\
\hline \multirow{7}{*}{ Al-1 } & \multirow{7}{*}{$\begin{array}{l}1 \rightarrow 2= \\
2^{\prime} \rightarrow 8 \\
\rightarrow 9 \rightarrow \\
10\end{array}$} & \multirow{7}{*}{1145} & \multirow{7}{*}{704} & \multirow{7}{*}{502} & \multirow{7}{*}{0.49} & 1650 & 704 & \multirow{7}{*}{608} & \multirow{7}{*}{0.87} \\
\hline & & & & & & \multicolumn{2}{|c|}{ Details } & & \\
\hline & & & & & & $1 \rightarrow 2$ & 826 & & \\
\hline & & & & & & $2^{\prime} \rightarrow 8$ & 30 & & \\
\hline & & & & & & $8 \rightarrow 9$ & 254 & & \\
\hline & & & & & & $9 \rightarrow 10$ & 318 & & \\
\hline & & & & & & $2 \rightarrow 2^{\prime}$ & 222 & & \\
\hline \multirow{6}{*}{ Al-2 } & \multirow{6}{*}{$\begin{array}{l}2 \rightarrow 3 \rightarrow \\
4=4^{\prime} \rightarrow \\
6\end{array}$} & \multirow{6}{*}{732} & \multirow{6}{*}{598} & \multirow{6}{*}{360} & \multirow{6}{*}{0.01} & 904 & \begin{tabular}{|l|}
598 \\
\end{tabular} & \multirow{6}{*}{414} & \multirow{6}{*}{0.01} \\
\hline & & & & & & Det: & & & \\
\hline & & & & & & $2 \rightarrow 3$ & 191 & & \\
\hline & & & & & & $3 \rightarrow 4$ & 191 & & \\
\hline & & & & & & $4^{\prime} \rightarrow 6$ & 405 & & \\
\hline & & & & & & $4 \rightarrow 4^{\prime}$ & 117 & & \\
\hline $\mathrm{Al}-4$ & $4 \rightarrow 5$ & 220 & 55 & 103 & 0.00 & 220 & 55 & 103 & 0.00 \\
\hline Al-5 & $5 \rightarrow 4^{\prime}$ & 230 & 59 & 108 & 0.00 & 230 & 59 & 108 & 0.00 \\
\hline \multirow{4}{*}{ A1-6 } & \multirow{4}{*}{$\begin{array}{l}6 \rightarrow 7 \rightarrow \\
2^{\prime}\end{array}$} & \multirow{4}{*}{720} & \multirow{4}{*}{598} & \multirow{4}{*}{356} & \multirow{4}{*}{0.01} & 796 & 598 & \multirow{4}{*}{381} & \multirow{4}{*}{0.00} \\
\hline & & & & & & Det: & & & \\
\hline & & & & & & $6 \rightarrow 7$ & 191 & & \\
\hline & & & & & & $7 \rightarrow 2^{\prime}$ & 605 & & \\
\hline \multirow{3}{*}{ Al-10 } & \multirow{3}{*}{$\begin{array}{l}10 \rightarrow 11 \\
\rightarrow 12\end{array}$} & \multirow{3}{*}{1145} & & & & 1271 & 704 & & \\
\hline & & & 704 & 502 & 0.4 & & & 532 & 012 \\
\hline & & & & & & $\begin{array}{l}10 \rightarrow 11 \\
11 \rightarrow 12\end{array}$ & $\begin{array}{l}953 \\
318\end{array}$ & & \\
\hline
\end{tabular}

Table 6 Stress values in stress path A-2, A-3 and A-4.

\begin{tabular}{|c|c|c|c|c|c|}
\hline \multirow{2}{*}{ Path } & \multirow{2}{*}{ Nf, exp. } & \multicolumn{2}{|c|}{ Wang-Brown method } & \multicolumn{2}{c|}{ Dong method } \\
\cline { 3 - 6 } & & Nf pre. & Nf ratio & Nf pre. & Nf ratio \\
\hline A-1 & $2.41 \times 10^{3}$ & $2.47 \times 10^{3}$ & 0.98 & $4.88 \times 10^{2}$ & 4.95 \\
\hline A-2 & $1.01 \times 10^{4}$ & $1.76 \times 10^{4}$ & 0.58 & $2.69 \times 10^{3}$ & 3.75 \\
\hline A-3 & $2.21 \times 10^{4}$ & $5.65 \times 10^{4}$ & 0.39 & $7.56 \times 10^{3}$ & 2.93 \\
\hline A-4 & $4.45 \times 10^{4}$ & $1.63 \times 10^{5}$ & 0.27 & $1.94 \times 10^{4}$ & 2.29 \\
\hline A-5 & $1.00 \times 10^{5}$ & $3.92 \times 10^{5}$ & 0.26 & $4.29 \times 10^{4}$ & 2.33 \\
\hline
\end{tabular}

Dong らの方法による予測寿命は，Wang-Brown 法の予測 結果と異なり寿命に因らずに実線の実寿命に対して $1 / 3$ 倍の安全側の破線付近に図示された. Dong らの方法は, Wang-Brown の方法と逆に di を実際よりも大きく評価し たと推定される、筆者らは，その原因として，応力範囲に 転回点と投影した転回点との距離を加えていることにあ ると推定するが，その検討については次報で行うことと する.

\section{$4 \cdot 4$ 試験片の破壊形態}

Fig. 11 に本研究の破断試験片の写真を示す. 図中の一 点鎖線は最大主応力の最大值の方向を, 実線は疲労破面 の向きを表す. 大川らは, $\tau_{\mathrm{a}} / \sigma_{\mathrm{a}}=0.5,2$ に対して位相角 $\varphi=$ $0^{\circ}, 90^{\circ}$ の高サイクル領域の多軸振幅一定疲労試験を行い, 4 条件でき裂は長さ $0.1 \mathrm{~mm}$ まで最大せん断応力の方向へ, $1 \mathrm{~mm}$ 以上で最大主応力の最大值の方向に対して垂直方向 へ進展したことを報告している ${ }^{20)}$. (a)(b)図より, 本件の一 定振幅疲労試験片でも最大主応力の最大值に垂直な方向 へき裂が進展した.ただし, 今回は試験中のき裂観察をし ていないので，き裂の発生方向は不明である. (c)(d)図よ り,波形 $\mathrm{A}$ 試験片は一定振幅疲労試験片と同様に平坦な 疲労破面が形成されて, 表面での最終疲労き裂長さは $2 \mathrm{~mm}$ 程度となった. 波形 $\mathrm{A}$ の破面の向きは図中の実線と 重なり, 疲労き裂はマクロ的に真直ぐ進展したことがわ かる. 一方, 波形 A の最大主応力の最大值は Time1 で生 じて垂直方向は $38^{\circ}$ となるが，試験片の破面角度は $16^{\circ}$

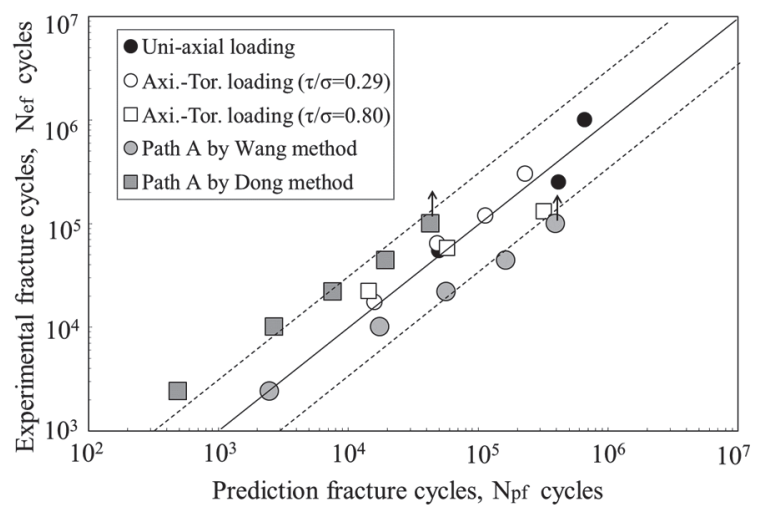

Fig. 10 Correlation between experimental life and predicted life for axial and torsional combined loading.
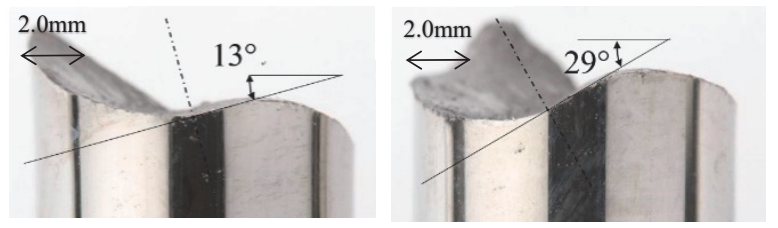

(a) $\tau_{\mathrm{a}} / \sigma_{\mathrm{a}}=0.29, \mathrm{~N}_{\mathrm{f}}=1.19 \times 10^{5}$

(b) $\tau_{\mathrm{a}} / \sigma_{\mathrm{a}}=0.80, \mathrm{~N}_{\mathrm{f}}=1.30 \times 10^{5}$

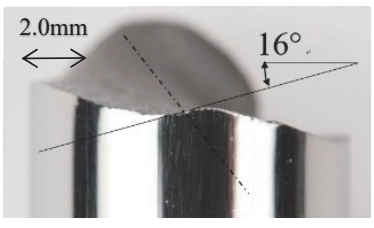

(c) A3, $\mathrm{N}_{\mathrm{f}}=2.21 \times 10^{4}$

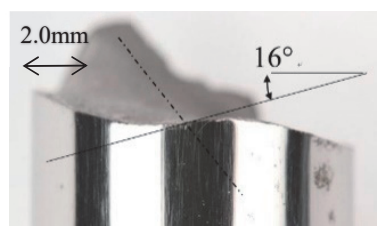

(d) $\mathrm{A} 4, \mathrm{~N}_{\mathrm{f}}=4.45 \times 10^{4}$
Fig. 11 Fractographic of the fatigue fracture specimens.

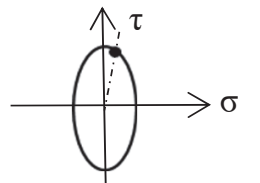

(a) $\tau_{\mathrm{a}} / \sigma_{\mathrm{a}}=2.0, \quad \varphi=90^{\circ}$

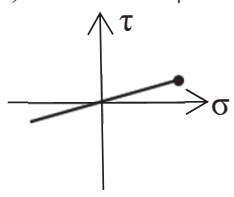

(c) $\tau_{\mathrm{a}} / \sigma_{\mathrm{a}}=0.29$

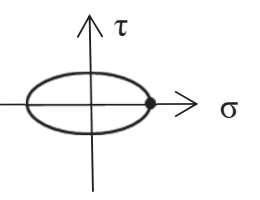

(b) $\tau_{\mathrm{a}} / \sigma_{\mathrm{a}}=0.5, \quad \varphi=90^{\circ}$

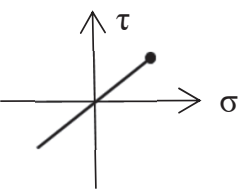

(d) $\tau_{\mathrm{a}} / \sigma_{\mathrm{a}}=0.80$

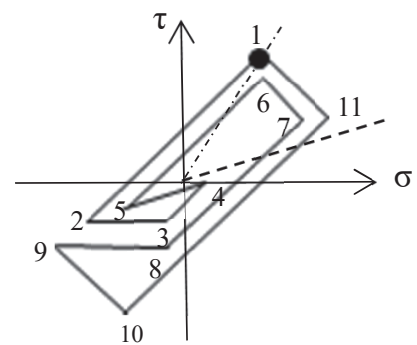

(e) Stress path A

Fig. 12 Stress Paths.

であった. き裂は最大主応力の最大值に垂直な方向一進 展していない. Fig. 12 (a)(b)に大川らの $\varphi=90^{\circ}$ で $\tau_{\mathrm{a}} / \sigma_{\mathrm{a}}=2.0$, 0.5 の応力軌跡を, (c)(d)(e)図に本研究での応力軌跡を示寸. 図中の黒点は最大主応力の最大值の応力を表す. (a)図の 一点鎖線は原点と黒点を結ぶ線を，(e)図の破線は試験片 
の破面角度が $16^{\circ}$ となるときの応力軌跡である. (a)(b)図よ り $\sigma$ と $\tau$ が同一周波数で 1 サイクルが閉じる場合, 1 サイ クル中の $\sigma$ と $\tau$ の小にかかわらずに最大主応力の最大 值により破面が形成されることがわかる. 一方, 波形 $\mathrm{A} の$ 試験片では, 最大主応力の最大值と破面の関係は明確で はなかった. 波形 $\mathrm{A}$ の応力軌跡は, 点 1 , 点 9 , 点 10 , 点 11 の四角形の軌跡と, 点 5 , 点 6 , 点 7 , 点 8 の四角形の 軌跡で構成されている. それぞれの最大主応力の最大值 点 1 と点 6 の方向は, 破線よりも㸚じり応力の比率が多 い. そのため, 破線方向に近い方向の応力である点 2 と点 3, 点 8 と点 9 の経路が破壊様相に関連している可能性が あるが，さらに異なる波形による疲労試験結果の検討が 必要である.

\section{5 結言}

本研究では，不規則に変動する軸力とねじりの組合せ 応力における疲労強度評価法として, 筆者らが提案して いる多軸一定振幅疲労の寿命予測法に Wang-Brown 法と Dong らの方法の適用を試みた。その評価法の検証に SNCM439 を用いた軸力とねじりを組合せた高サイクル 領域における多軸変動振幅疲労試験を行った. その結果, Wang-Brown 法は実寿命よりも長めの寿命を, Dong らの 方法は短めの寿命を予測した。その理由として, WangBrown 法は各応力経路の開始点と終点との直線距離を応 力範囲とするので経路を短く算出すること, Dong らの方 法は経路長として, 経路の距離に転回点と投影した転回 点との距離を加えることで経路を長く算出していると考 えられる. また, 高サイクル領域における一定振幅疲労試 験により破断した試験片は, 最大主応力方向に垂直な方 向に破面が形成されたが, 変動振幅疲労試験の試験片は, 変動荷重の内の最大主応力の最大值に加えて他の経路の 影響も含まれて破面が形成されることが推定された。

\section{参 考 文 献}

1) G. Matsubara and K. Nishio, "Multiaxial high-cycle fatigue criterion considering crack initiation and nonpropagation", International Journal of Fatigue, Vol. 47, pp. 222-231 (2013).

2) G. Matsubara and K. Nishio, "Multiaxial high-cycle fatigue criterion for notches and superficial small holes from considerations of crack initiation and nonpropagation", International Journal of Fatigue, Vol. 67, pp. 28-37 (2014).

3) G. Matsubara, A. Hayashida and D. Kano, "Multiaxial High Cycle Fatigue Life Prediction under Constant Stress Amplitude", Journal of the Society of Material Science, Japan, Vol. 66, No. 9, pp. 667-674 (2017).

4) G. Matsubara, A. Hayashida and D. Kano, "Predicting the multiaxial fatigue limit and the multiaxial high-cycle fatigue life based on the unified equivalent shear stress from axial strength characteristics with various waveforms", International Journal of Fatigue, Vol. 112, pp. 52-62 (2018).
5) H. Nakamura, M. Takahashi, T. Itoh, M. Wu and M, Sakane, "Development of visualizing method for loading history and design method under non-proportional multiaxial loading" Transactions of the JSME, Series A, Vol.79, No.798 (2013-12), pp.198-208.

6) A. Fatemi and N. Shamsaei, "Multiaxial fatigue: An overview and some approximation models for life estimation", International Journal of Fatigue, Vol. 33, pp. 948-958 (2011).

7) ICMFF12, MATEC Web of Conferences 300, (2019)

8) "Special Issue : ICMFF11", International Journal of Fatigue, Vol. 100, Part 2, pp. 453-650 (2017).

9) A. Fatemi and D. F. Socie, "A critical plane approach to multiaxial fatigue damage including out-of-phase loading”, Fatigue \& Fracture of Engineering Materials \& Structures, Vol. 11, No. 3, pp. 367-370(1998).

10) R. N. Smith, P. Watson and T. H. Topper, "A stress-strain function for the fatigue of metals", Journal of Materials, Vol. 5, pp. 767-778(1970).

11) G. Sines, "Failure of materials under combined repeated stresses with superimposed static stresses", NACA Technical Note 3495 (1955).

12) B. Crossland, "Effect of large hydrostatic pressure on the torsional fatigue strength of an alloy steel", Proceedings of the international conference on fatigue of metals, Institute of Mechanical Engineers, pp. 138-149 (1956).

13) J. A. Bannantine and D. F, Socie, "A multiaxial fatigue life estimation technique”, ASTM STP1122, pp. 249-275 (1992).

14) C. H. Wang and M. W. Brown, "Life prediction techniques for variable amplitude multiaxial fatiguePart 1: Theories", Journal of Engineering Materials and Technology, Vo.118, No.3, pp. 367-370 (1996).

15) P. Dong, Z. Wei and J. K. Hong, "A path-dependent cycle counting method for variable-amplitude multi-axial loading", International Journal of Fatigue, Vol. 32, Iss. 4, pp. 720-734(2010)

16) V. Anes, L. Reis, B. Li, M. Fonte and M. de Freitas, "New approach for analysis of complex multiaxial loading paths," International Journal of Fatigue, Vol.62, pp. 2231 (2014).

17) C. H. Wang and M. W. Brown, "Life prediction techniques for variable amplitude multiaxial fatiguePart 2: Comparison with experimental results", Journal of Engineering Materials and Technology, Vo.118, No.3, pp. 371-374 (1996).

18) K. Ohji, M. Tsuji, S. Kubo, Y. Ono, A. Yahata and K. Umei, "Predictions of fatigue crack propagation path and life of high-tension steel in residual stress fields", Transactions of the JSME, Series A, Vol.59, No.562 (1993-6), pp.1429-1436.

19) K. Tanaka, Y. Akiniwa, T. Mikuriya and K. Tanaka, "Propagation and arrest of fatigue cracks from a precrack under cyclic torsional loading in mediumcarbon steel", Transactions of the JSME, Series A, Vol.67, No.664 (2001-12), pp.2032-2038.

20) I. Ohkawa, H. Takahashi, M. Moriwaki and M. Misumi, "A study on fatigue crack growth under out-of-phase combined loadings," Fatigue \& Fracture of Engineering Materials \& Structures, Vol.20, No.6, pp. 929-940 (1997). 